\title{
17 WRZEŚNIA 1939 ROKU NA KRESACH WSCHODNICH W PROPAGANDZIE RADZIECKIE] ORAZ WE WSPÓŁCZESNYM SPOJRZENIU POLAKÓW I BIAŁORUSINÓW
}

\section{Anna KULESZEWICZ}

\section{ABSTRACT}

\section{SOVIET AGRESSION TO POLAND OF SEPTEMBER 17, 1939 IN A SOVIET PROPAGANDA AND IN THE CONTEMPORARY COUNCIOUSNESS OF POLES AND BELARUSIANS}

On September 17, 1939, on the strength of the Ribbentrop-Molotov Pact established on August 23, 1939, Soviet troops carried out armed aggression on the Second Polish Republic without official declaration of war. As a result - Polish territories were divided between Germany and the USSR: the eastern territories of the country were influenced by the Kremlin and part of the eastern territories of the Second Polish Republic was incorporated into the Belorusian Soviet Socialist Republic.

All war and aggressive activities required not only a deliberate military plan, but also the preparation of an appropriate propaganda ground: propaganda was a tool for creating the necessary background among the masses of the population and on the international arena.

Propaganda was used by both the Polish and the Soviet sides: before, during and after the war. Before the war, Poles focused more on Nazi Germans, although some circles of the intelligentsia showed great interest in Soviet Russia. As for current awareness and official interpretation in relation to the events of September 17, 1939, they are considered an act of aggression.

Propaganda has always been a strong weapon in the hands of the Soviets. Using this tool, they tried to create a ground and "justify" the aggression against Poland, a myth about the necessity of freeing the oppressed Ukrainians and Belarusians was invented, repeated until the collapse of the USSR. Currently, it is still possible to observe suchan interpretation in Belarus, although the situation is slowly changing, aiming at the recognition of historical truth.

\section{KEYWORDS:}


17 września 1939 roku, na mocy ustalonego 23 sierpnia 1939 roku paktu Ribbentrop-Mołotow, wojska sowieckie dokonały zbrojnej agresji na II Rzeczpospolitą bez oficjalnego wypowiedzenia wojny'. W jej następstwie doszło do podziału polskich ziem, dokonanego przez państwa zaborcze - hitlerowskie Niemcy i ZSRR. W wyniku rozbioru (nazywanego przez część badaczy „IV rozbiorem Polski” ) wschodnie terytoria kraju znalazły się pod wpływami Kremla, a część ziem wschodnich II Rzeczpospolitej została przyłączona do BSRR. Jak zauważa jeden z badaczy, Jerzy Łojek, istota konsekwencji paktu Ribbentrop-Mołotow nie dotyczy jedynie Polski, Niemiec i Związku Radzieckiego - w jego opinii bez tego tajnego układu druga wojna światowa nie wybuchłaby już w 1939 roku, albo też nie wybuchłaby w ogóle ${ }^{3}$.

\section{PRZED AGRESJA - SUTUACJA W EUROPIE}

Porząadek, jaki panował w Europie do września 1939 roku, gwarantowany był przez „ład wersalski”, zapewniać miał on pokój na kontynencie oraz bezpieczeństwo Polski. Jednakże ów ład, ustanowiony w roku 1919, z czasem stał się „niewygodny” dla poszczególnych państw. Do jego pierwszego znacznego naruszenia doszło w 1938 roku przy okazji uchwalenia „układu w Monachium”. Wśród większości amerykańskich i europejskich polityków pojawiło się wówczas błędne przekonanie, jakoby Związek Radziecki mógł być zainteresowany powstrzymaniem politycznej i terytorialnej ekspansji Adolfa Hitlera. W państwie Stalina zaczęto wręcz widzieć potencjalnego sojusznika. Jak zauważa Jerzy Łojek, „nikt prawie nie zastanawiał się nad sprawą najważniejszą: w imię czego Związek Radziecki - gdyby był nawet ówcześnie zdolny do udziału w wojnie przeciwko Rzeszy - miałby się angażować po stronie demokracji zachodnich i Polski, dla ocalenia systemów tzw. kapitalistycznych przed Rzeszą Niemiecką Adolfa Hitlera?”

Tymczasem nie dostrzegano pewnej niebezpiecznej zbieżności w celach politycznych Związku Radzieckiego i III Rzeszy - zarówno Hitler, jak i Stalin pragnęli obalić królujący w Europie „ład wersalski”. Znamienna dla losów Europy i przebiegu wydarzeń drugiej wojny mogłaby być zgoda Polski na wspólne uderzenie z III Rzeszą na Związek Radziecki - wszak Hitler dłuższy czas kusił polskie władze taką perspektywą (ostatni raz w lutym 1939 roku podczas wizyty Józefa Becka w Berchtesgaden i Joachima

J. Łojek, Agresja 17 września 1939, Warszawa 1990, s. 10.

D. Rotfeld, A.W. Torkunow (red.), Biate plamy - czarne plamy. Sprawy trudne w relacjach polsko-rosyjskich (1918-2008), Warszawa 2010, s. 219, 264.

J. Łojek, dz. cyt., s. 9-10.

Tamże, s. 10-11. 
von Ribbentropa w Warszawie). Rząd Polski jednakże uznał, że konflikt zbrojny z ZSRR nie leży w interesie kraju, nie przewidując konsekwencji tej decyzji oraz późniejszych wydarzeń ${ }^{5}$.

Adolf Hitler ze swoich planów wprowadzenia nowego porządku w Europie nie zrezygnowal, nie rezygnował z nich także Józef Stalin, który w 1939 roku dostrzegł szansę realizacji politycznego planu aneksji Finlandii, Estonii, Łotwy, Litwy, połowy Polski i części Rumunii przy użyciu sił III Rzeszy. Z perspektywy historycznej wydawać się może aż zdumiewające, że elity polskie i europejskie nie dostrzegły nieuchronności radziecko-niemieckiego paktu, który zwyczajnie wynikał z logiki ówczesnej sytuacji międzynarodowej oraz fundamentalnej wspólnoty celów politycznych tych dwóch mocarstw ${ }^{6}$.

Dlaczego polscy politycy, biorąc pod uwagę położenie pomiędzy tymi dwoma wielkimi graczami na europejskiej arenie międzynarodowej, nie widzieli tak realnego zagrożenia? Postrzeganie Związku Radzieckiego jako największego zagranicznego źródła niebezpieczeństwa umarło wraz z Józefem Piłsudskim, który jeszcze na ostatnim swoim posiedzeniu z grupą oficerów Sztabu Głównego podnosił tę kwestię. W jego ocenie, mimo większego prawdopodobieństwa zbrojnego ataku ze strony III Rzeszy, Polska powinna bardziej obawiać się Związku Radzieckiego. Agresja Rzeszy mogła wywołać reakcję innych państw zachodnich, agresja ZSRR - najprawdopodobniej nie, z uwagi na odległość, brak realnego zagrożenia dla Francji czy Anglii oraz enigmatyczną wiedzę o tej „białej plamie w Europie Wschodniej””.

Za rządów Józefa Becka skupiono się jednak przede wszystkim na postrzeganiu III Rzeszy jako zagrożenia - głównie za sprawą licznych propagandowych politycznych i prasowych „ataków” na Polskę (ze strony ZSRR polityczne potyczki słowne nie były tak wyraźne). Polityka Józefa Becka, obierająca za jeden z głównych celów przeciwstawienie się hitlerowskiemu programowi ekspansji, byłaby jak najbardziej sensowna, gdyby nie doszło do paktu pomiędzy Niemcami a Sowietami. Beck uważał, że spory niemiecko-radzieckie są na tyle głębokie i będą tak trwać długo, iż o żadnym zbliżeniu nie ma mowy (według jednego ze współpracowników ministra Beck „myślał, że spór niemiecko-sowiecki będzie trwał wiecznie z powodu diatryb Hitlera przeciw komunizmowi i Sowietom"8). Nie zauważał on, że w interesach obydwu mocarstw więcej jest zbieżności niż punktów konfliktowych. Jak pisał Władysław W. Kulski

Tamże, s. $15-16$.

Tamże, s. 10-12.

Tamże, s 12-13.

Tamże, s. 11. 
w Pamiętniku b. polskiego dyplomaty: „układ Hitlera ze Stalinem w 1939 roku był dla Becka gorzką niespodzianką"”.

\section{PRZED AGRESJĄ - PROPAGANDA RZĄDU 11 RP}

$\mathrm{W}$ dyskursie politycznym prowadzonym $\mathrm{w}$ drugiej połowie lat trzydziestych przez rząd polski dominowała retoryka postrzegania III Rzeszy jako głównego zagrożenia i potencjalnego agresora, toteż przeciwko sąsiadowi z zachodu ukierunkowana była negatywna propaganda. Do tego pamiętać należy o swoistym zadufaniu rządu II RP, który zdawał się nieświadomy kruchości polskiej niepodległości, słabości ekonomicznej, militarnej oraz położenia geograficznego i dawał społeczeństwu do zrozumienia, że II Rzeczpospolita jest „ósmym mocarstwem świata”, a jej siły militarne przyrównać można do możliwości bojowych armii niemieckiej. $\mathrm{W}$ efekcie tych działań opinia publiczna przyjmowała do świadomości jedynie definitywną ewentualność stawienia oporu wobec żądań i poczynań Hitlera, pod uwagę nie brano nawet żadnej opcji ewentualnego kompromisu. Ponadto zarówno politycy, jak i społeczeństwo żywili zaufanie do obowiązujących wówczas międzynarodowych paktów pokojowych i porozumień o współpracy ${ }^{10}$.

Jeśli mówić o rodzaju propagandy czy kształtującej się opinii społecznej dotyczącej postrzegania Związku Radzieckiego w międzywojennej Polsce, przyjrzeć się można bliżej publikacjom prasowym, szczególnie w piłsudczykowskich czasopismach - to właśnie prasa wywierała wpływ na powszechny stosunek wobec bolszewizmu, choć docierała głównie do kręgów inteligenckich ". „Wielki wschodni sąsiad” budził zainteresowanie wśród wszystkich kręgów wykształconych warstw społecznych i sił politycznych. Zwykle stosunek do ZSRR był krytyczny, a aspektami najczęściej poddawanymi negatywnemu osądowi były brak demokracji w kraju rad, jego nadmierna centralizacja, a także terror oraz fatalna polityka gospodarcza; spora część publicystów podkreślała także, iż polityka uprawiana przez rząd radziecki nie jest w rzeczywistości zgodna z ideami marksistowskimi ${ }^{12}$. Na przestrzeni lat poglądy i opinie ulegały pewnym zmianom, stopniowo $\mathrm{z}$ negatywnych przekształcały się $\mathrm{w}$ bardziej umiarkowane, pragmatycznie oceniające bolszewizm (wpływ na to miała także sytuacja międzynarodowa, pakty o nieagresji, snute wizje o swoistej szansie współpracy z Sowietami). Niemniej

W.W. Kulski, Pamiętnik b. polskiego dyplomaty, „Zeszyty Historyczne”, nr 42, Paryż 1977, s. 159-160, cyt. za: J. Łojek, dz. cyt., s. 11.

J. Łojek, dz. cyt., s. 13-14.

I. Stadnyi, Obraz ZSRR w pitsudczykowskich czasopismach spoteczno-politycznych (1922-1939), [w:] „Nowy Prometeusz” 2013, nr 4, s. 161.

12 Tamże, s. 162-167. 
jednak niektóre z pozycji prasy piłsudczykowskiej stale utrzymywały raczej krytyczny kurs w odniesieniu do wschodniego sąsiada - przykładem może być środowisko prometeistów skupione wokół pism Instytutu Wschodniego. Nastawienie do ZSRR w publikowanych tekstach było wrogie i pogardliwe (podkreślano pejoratywne cechy „psychiki” rosyjskiej: turpizm, mongolizm; a także „azjatyckość” korzeni ZSRR), postrzegano komunizm jako system, który opierał się na terrorze, donosicielstwie i poniżeniu jednostki (poza piłsudczykowskimi czasopismami wymienić tu można również powieści Sergiusza Piaseckiego) ${ }^{13}$.

Poza kształtowaniem przez prasę opinii publicznej zabrakło jednakże odgórnych antyradzieckich działań propagandowych na dużą skalę. Wyjątek stanowią wysiłki Korpusu Ochrony Pogranicza, którego członkowie starali się budować negatywny obraz Związku Radzieckiego w świadomości ludności lokalnej na terenach przygranicznych ${ }^{14}$.

\section{PRZED AGRESJA - PROPAGANDA ZSRR}

Propaganda w Związku Radzieckim stanowiła jeden z trzonów władzy, filarów, które dźwigały ciężar funkcjonowania państwa. Stalin i jego współpracownicy zdawali sobie sprawę, że jest ona potężnym narzędziem, które - odpowiednio użyte - pozwala wytworzyć w społeczeństwie pożądany sposób myślenia, umożliwiający jego całkowite podporządkowanie. Planowana agresja na Polskę musiała mieć swoje uzasadnienie do jego „wytworzenia” wykorzystano właśnie propagandę

$\mathrm{Na}$ wstępie należy zaznaczyć, że propagandowe działania przeciwko II Rzeczpospolitej miały dać Sowietom możliwość usprawiedliwienia i legitymizacji agresji nie tylko wśród własnych obywateli, lecz także, przede wszystkim, na arenie międzynarodowej.Jak zauważa Jakub Zyska, owa agitacja (posiadająca charakterystyczną cechę kampanijności działania) okazała się na tyle skuteczna, że dezaprobata wobec poczynań ZSRR wyrażona została dopiero 14 grudnia 1939 roku po agresji na Finlandię (wówczas to Związek Radziecki wykluczony został z Ligi Narodów) ${ }^{16}$.

Do krytyki II RP wykorzystano rządowe dzienniki - „Prawdę” oraz „Izwiestia”, w których rozpoczęła się zmasowana kampania przeciwko władzom Polski, oskarżanym o uciskanie „braci Białorusinów i Ukraińców”. Krótko potem rozpoczęły się działania mające na celu wzmocnienie obsad głównych obiektów na terenie Związku Radzieckiego, co zbiegło się z ogólną informacją o mobilizacji Armii Czerwonej w kilku wojskowych

\footnotetext{
Tamże.

Tamże, s. 170-174.

J. Zyska, Sowiecka propaganda we wrześniu 1939 roku, źródło: http://www.nowastrategia.org.pl/sowieckapropaganda-we-wrzesniu-1939-roku/ [dostęp: 10.07.2017].

16 Tamże.
} 
obszarach - miało to być przygotowanie na ewentualną próbę wciągnięcia kraju w „imperialistyczną wojnę”. Natomiast na kilka dni przed 17 września w dostępnych radzieckich mediach (prasa, radio) obwieszczane były komunikaty o prowokacjach dokonywanych przez oddziały polskie na granicy oraz o przypadkach naruszenia sowieckiej granicy przez polskie lotnictwo ${ }^{17}$.

Fałszywe przesłanki o rzekomych aktach wrogości i prowokacji ze strony polskiej wobec ZSRR docierały także do Polski. Dwa dni przed sowiecką agresją, 15 września 1939 roku, wydawana w Wilnie gazeta „Słowo” zamieściła na swych łamach artykuł informujący o „zgrzycie” pomiędzy Polską a Związkiem Radzieckim, którego powodem było oskarżenie wymierzone przeciwko polskiemu lotnictwu (mającemu rzekomo naruszyć granicę ZSRR) przez sowiecką agencję TASS. Artykuł umieszczony był dopiero na trzeciej stronie gazety, co pozwala stwierdzić, że nie traktowano tej sprawy ani priorytetowo, ani odpowiednio poważnie. Autor tekstu wyraził swoje przekonanie o tym, że całemu zamieszaniu winna jest niemiecka propaganda. W kraju przejętym dramatyczną defensywą w obliczu niemieckiej kampanii wrześniowej nie spodziewano się, że prowokacyjne treści wyrażane w mediach radzieckich są tak naprawdę swoistym

\section{To już jawna prowokacja!}

Wczoraj rano radjo moskiew skie ogłosiło komunikat, iz Polska naruszyła rzekomo granice suwerenne SSSR., przelatując je wojskowemi samolotami.

Oczywista bujda.

Samoloty, według relacji "Tassa" mialy być odstraszone artylerją przeciwlotniczą, a w dwóch okolícznościach nawet lądowały przymusowo.

Radjo sowieckie nadalo ten komunikat okolo godziny 11-ej rano. Ale już o drugiej radjo riemieckie, t. zw. Deutschland Sender podały go już nie w formie lakonicznej, a obszernej. Wymienione są szczególowe miej scowości, aparaty, okoliczności, daty i t. d. Ton komunikatu niemieckiego miał wyraźnie brzmie nie tryumfujące. Jednem słowem tu i tam, Poiacy lataja na swych wojennych maszynach, przekraczaja granice cichej, spo kojnej Rosji, neutralnych Sowietów, naruszają jej bezpieczeń wszystkich państw na świecie zależy oczywiście na uwikłanie Polski w dodatkowy konflikt na jej tyłach. - Jasność tej sytuacji nie wymaga chyba żadnych komentarzy.

Polska, której armje walczą a jej zachodnim froncie, zaabsorbowana jest w tej walce wszystkiemi swojemi siłami, wobec przeważajacego naporu niemieckiego i w takiej sytuacji potrzebny i wazny jest dla niej każdy samolot wojenny na froncie. Niedopomyślenia jest zatem, by szafowała niemi dia bezcelowych przelotów wzdłuż granicy sowieckiej. Odpada więc nawet przypuszczenie, iz mogly to być polskie samoloty zbłąkane.

Polsce zależy na dobrych sto sunkach Polski z Sowietami. Niemcom zależy na zlych stosunkach Polski z Sowietami.

Mogly byé to zatem jedynie wylącznie samoloty niemieckie tóre umyślnie, z rozkazu Hitle- preludium do ataku na Polskę, jakiego miała niebawem dokonać Armia Czerwona ${ }^{18}$.

\section{Ruc. 1. Fragment artykułu z gazety Słowo" informujący o rzekomym naruszeniu granicy Związku Radzieckiego przez polskie samoloty Fot. Andrzej Poczobut. żródło: https://scontent fwaw3-1.fno. fbcdn.net/v/t1.0-9/21730950 848635455302709 2579033890328503324_n jpg?oh= e77b6713f987198cf5bec5e880b26 283qoe=5AADD5E 7}

Tamże.

18 A. Poczobut, \#Wrzesien1939, źródło: https://www.facebook.com/photo.php?fbid=84863545530270 9\&set=pb.100004687862170.-2207520000.1510179812.\&type=3\&theater [dostęp: 9.11.2017]. 
Mimo że antypolska propaganda w sowieckiej prasie wzbudzała pewne zaniepokojenie przedstawicieli polskich władz, nie udało się przewidzieć dalszych wydarzeń. Tymczasem machina propagandy mającej uzasadnić agresję nabierała rozpędu, wkraczając na pole dyplomatyczne: 17 września 1939 roku, o godzinie trzeciej w nocy do siedziby Ludowego Komisariatu Spraw Zagranicznych w Moskwie wezwano polskiego ambasadora Wacława Grzybowskiego i wręczono mu oficjalną notę fałszywie traktującą o ówczesnym stanie państwa polskiego, uzasadniającą - za pomocą propagandowej radzieckiej retoryki - zbrojne wtargnięcie na teren II RP, które nastąpiło kilka godzin później ${ }^{19}$.

Treść noty, odrzucona oraz uznana za kłamliwą i pełną oszczerstw przez ambasadora przedstawia się następująco:

Wojna niemiecko-polska pokazała wewnętrzne bankructwo państwa polskiego. $W$ ciagu 10 dni operacji wojskowych Polska utraciła wszystkie swoje zagłębia przemysłowe i ośrodki kulturalne. Warszawa jako stolica Polski już nie istnieje. Rzad polski już nie istnieje. Oznacza to, iż państwo polskie i jego rząd faktycznie przestaty istnieć. Tym samym traktaty zawarte przez Z.S.R.R. i Polskę stracity ważność. Pozostawiona własnemu losowi i pozbawiona kierownictwa, Polska stała się tatwym polem działania dla wszelkiego rodzaju poczynań i niespodzianek, mogacych stać się groźba dla Z.S.R.R.. Dlatego też rzad sowiecki, który zachowywat dotąd neutralność, nie może pozostać dłużej neutralnym w obliczu tych faktów. Rząd sowiecki nie może również pozostać obojętnym w chwili, gdy bracia tej samej krwi, Ukraińcy i Białorusini, zamieszkujacy na terytorium Polski i pozostawieni swemu losowi, znajduja się bez żadnej obrony.

Biorac pod uwagę tę sytuację, rząd sowiecki wydat rozkazy naczelnemu dowództwu Armii Czerwonej, aby jej oddzialy przekroczyly granicę i wzięty pod obronę życie i mienie ludności zachodniej Ukrainy i zachodniej Białorusi.

Rząd sowiecki zamierza jednocześnie podjać wszelkie wysitki, aby uwolnić lud polski od nieszczęsnej wojny, w którą wpędzili go nierozsądni przywódcy, i dać mu możliwość egzystencji w warunkach pokojowych.

Podpisano: Komisarz ludowy spraw zagranicznych ${ }^{2}$

Nie była to jedyna metoda propagandy, na jaką zdecydowały się władze radzieckie wraz z momentem wkroczenia na teren II Rzeczpospolitej. Należy też wspomnieć o kolportowanych ulotkach propagandowych, jakie rozpowszechniano wśród ludności lokalnej. Miały one podkreślać „pokojowe” $\mathrm{i}$ „uzasadnione” działania Sowietów oraz odpowiednio nakierunkować nastroje miejscowych mieszkańców w stosunku do Armii Czerwonej. Mimo niekiedy prymitywnej i słabej formy oraz

\footnotetext{
J. Zyska, dz. cyt.
}

20 Tamże. 
niepoprawnej polszczyzny, na niektórych obszarach ulotki odniosły oczekiwany skutek, choć najczęściej wśród zwolenników komunizmu oraz mniejszości narodowych.

\section{Rzolnierze Armii Polskiej!}

Pańsko-burzuazjny Rząd Polsil, wolągnowszy Was w awanturystyczną wojnę, pozornie przevalilı się. Ono okazalo się bezsilnym rządzić krajem i zorganizawać obronu. Ministrzy I gienerałowie, schwycill nagrabione im zloto, tchórzliwie ubiekll, pozostawiają armlę I cały lud Polski na wolę losu.

Armia Polska pocierpiela surawą porazke, od którego ona nle oprawió wstanie się. Wam, waszym ṫonom, dzieciam, braciam i slostram ugraza głodina śmierć I zniszczenie.

W te sięziaie dni dla Was potętny Związek Radziscki wyciagga Wam ręce bratarskiej pomocy. Nie przeciwcle się RohotniczoChłopskiej Armii Czerwanej, V asze przeciewenie bez kożyści I przerzeczono na calą zgubę, 1 , idziemy do Was nie jako zdobjwcy, a jetse wasi bracl po $h_{2}$ isu, jako wasi ws waleriey oc ucisku obszarników I kapitalistów:

Wielka i niezwolczona Armia Czerwona niesie na swoich sztandarach procującym, braterstwo $I$ szczęśliwe żyeie.

Rzolnierze Armil Polskiej! Nit3 proliwacie doremnie krwi za cudze Wam interesy obszarnlkón I kapitallstów.

Was przymuszają uciskać bíłłorusinów, ukraincoów. Rządzące kole Polskie sieją narodową ruznoóć między polakami, białorusinami i ukraincami.

Pamiotainiel Nle može być syrobodny naród, uciskające drugie narody. Pracejące białorusini I tkraińcy-Wasl procujące, a nle wrogl. Razem z nimi budujcle sz zzęśliwe dorobkowe zycle.

Rzuoajcie brońl Przechodżce na stronę Armit Gzerwonej.

Wam zabezpieczona swoboda i szozęśliwe zycle.

Naczelny Dowódca Bialoruskiego frontu

Komandarm Drugie, kangt Michat KOWALOW.

17 września 1939 roku.

\section{LOLNIERZE!}

W ciągu ostatnich dni armja polska zostala ostatécznietrozgromiona. Zołnierze miast: Tarwỏpol, Galicz, Kówno, Dubno w thośel arzeszla 60.000 osób dobrowolnie przeszll na nasad stronę

Zolnierze! Co po\%ostało wam? O co $\mathrm{I}$ z kim walczýcie? Dla czego narażacie zycie? Opór wasz jest bezskuteczny. Oiicerowie pędza wás na bezsensowną rzeż. Oni nienawidzą was I trasze rodziny. To oni rozstrzelali waszych delégáxów, których posłaliście z propozycją o poddanlu się. Nie wierzcie swym oficerom. Offcerowie i generałowie są waszymi wrogami, dica oni waszej śmierci.

Zolnierze! Bijcie oficerów i generałów. Nle podporządkowujcie się rozkazom waszych offcerów. Pędźcie idı z waszej ziemi. Przechodźcle śmialo do nas, do waszych braci, do Armji Czerworiej Tu znajdzlecie uwage I troskliwość.

Pamictajcie, ze tylko Armja Czerwona . Dog woll naród polski z nieszczęsnej wojny, I uzyskacie możność rozpocząć pokojowe zycle.

Wierzcle nam! Armja Caerwona Związls radzicokiego 0 - to wasz jedyny. przyjaclel.

Dowódca frontu. Ukralískiego S. THMOSZEntó

\begin{abstract}
Ryc. 2. Jedna z ulotek rozpowszechnianych
przez Sowietów po wkroczeniu na ziemie 11 RP

we wrześniu 1939 roku. Żródło: http://www

nowastrategia.org.pl/sowiecka-propaganda-we-
\end{abstract}

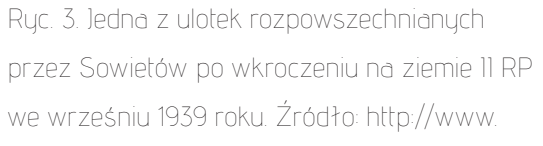

nowastrategia.org.pl/sowiecka-propaganda-we-wrzesniu-1939-roku/

Ulotki nie były jednak ostatnim narzędziem propagandy i sowietyzacji, jakie wykorzystano - w miarę zajmowania kolejnych części dawnych wschodnich ziem polskich rozpowszechniano sowiecką prasę wydawaną w języku polskim (pierwsze było „Słowo Żołnierza”, jakie poczęto wydawać w Tarnopolu, później pojawiły się inne „gadzinówki”, na przykład „Wolna Łomża” czy „Wyzwolony Białystok”). Prasa była Sowietom potrzebna przede wszystkim do wydawania i kolportowania przetłumaczonych radzieckich odzew do polskich żołnierzy, nawoływania do złożenia broni oraz szerzenia informacji o postępie Armii Czerwonej na froncie. W pierwszym 
okresie poziom językowy gazet i czasopism był bardzo niski, treści wyrażane kaleką polszczyzną zawierały wiele błędów i rusycyzmów.

\section{REAKC]E LUDNOŚCI NA AGRES]Ę}

16 września 1939 roku Rada Wojenna Frontu Białoruskiego wydała jednostkom Armii Czerwonej rozkaz nr 005 wkroczenia na terytorium II RP 17 września 1939 roku o godzinie 5.00 (czasu moskiewskiego) i rozbicia zajętego zmaganiami z siłami niemieckimi Wojska Polskiego ${ }^{21}$. W owym rozkazie, poza samym poleceniem, zawarte były także oficjalne motywy agresji - jako jedno z głównych uzasadnień podawano bezwzględny ucisk ludu pracującego Zachodniej Białorusi i Zachodniej Ukrainy oraz jego wyzyskiwanie przez polskich obszarników i kapitalistów. Rozpowszechniano pogląd, że ów stosowany ucisk oraz zniewolenie stały się głównymi przyczynami klęski II Rzeczpospolitej w kampanii wrześniowej. Ostateczna klęska „pańskiej Polski” oraz „wyzwoleńcza wizja” zbliżającej się Armii Czerwonej zachęcić miały chłopstwo rosyjskie i białoruskie do wzniecenia powstania przeciwko polskim władzom. Treść rozkazu zawierała zdanie: „nie jako zdobywcy, lecz jako wyzwoliciele naszych braci Białorusinów, Ukraińców i ludu pracującego Polski”22.

Teza o „wyzwoleńczym marszu” została przez propagandę sowiecką uznana za główny motyw dalszych działań. Pierwszy sekretarz Komitetu Centralnego Komunistycznej Partii Białorusi Ponomarienko zrelacjonował korespondentowi gazety „Prawda”: „Wsie błyszczą czerwonymi flagami, na ulicach nieprzerwane wiwatowanie”23. Takich propagandowych relacji było więcej - nie wszystkie zmyślone. Część ludności kresowej faktycznie witała Armię Czerwoną z nieudawaną radością, wywieszano flagi, tworzono nawet bramy triumfalne, wkraczające wojska witano okrzykami: „Niech żyje Stalin!”, „Niech żyje władza radziecka!”24.

Najmniej „radości” okazywała ludność polska, świadoma swej tożsamości narodowej, w największym stopniu gromkie powitania były organizowane wśród wiejskiej ludności białoruskiej, a w miastach - wśród Żydów komunistów. Najwięcej „entuzjastycznych” powitań odbyło się w miejscach, gdzie znajdowali się działacze komunistyczni. Tam, gdzie ich zabrakło, powitania Armii Czerwonej nie były już tak huczne, albo nawet nie było ich wcale. Ponadto samo „wystawne powitanie” wojsk

M. Wierzbicki, Polacy i Biatorusini w zaborze sowieckim: stosunki polsko-biatoruskie na ziemiach pótnocnowschodnich II RP pod okupacją sowiecka (1939-1941), Warszawa 2007, s. 45.

Tamże, s. 46.

Tam ze, s. 46.

Tamże, s. 46-47. 
radzieckich nie mogło przesądzić o nastrojach całej społeczności danej wsi czy gminy - wśród entuzjastów mogły się znaleźć osoby bierne lub wręcz wrogo nastawione do Sowietów, lecz bezradne w zaistniałej sytuacji. Wiadomo, że część ludności białoruskiej i żydowskiej obawiała się Armii Czerwonej, zwłaszcza w rejonach przygranicznych, gdzie zadziałała propaganda KOP-u. Analizując przebieg gromkich powitań ${ }^{25}$, zauważyć można prawidłowość, że im dalej Armia Czerwona posuwała się na zachód, tym huczniejsze i bardziej staranne powitania na nią czekały. Do wsi położnych na wschodzie wojska radzieckie wkroczyły szybko, zanim dotarly do bardziej oddalonych od granicy w kierunku zachodnim miejscowości, minęło więcej czasu - czasu, który sowieccy agitatorzy mogli wykorzystać na propagandowe przygotowanie ich powitania ${ }^{26}$.

Widząc bieg wydarzeń oraz postawę części społeczeństwa kresowego, polskie służby i wojsko, gdy jeszcze mogły, reagowały, starając się stłumić prosowiecki entuzjazm mieszkańców, jednakże krwawe represje za żywiołowe witanie Armii Czerwonej były sporadyczne ${ }^{27}$.

\section{AGRESJA RADZIECKA - OBRAZ W OKRESIE PRL-U}

W okresie PRL-u temat agresji radzieckiej najczęściej był zwyczajnie pomijany. Gdy już pojawiła się konieczność podniesienia kwestii tamtych wydarzeń, opisywano je jako nadejście Armii Czerwonej z zamiarem pomocy ludności terenów wschodnich, którą planowano uchronić przed Niemcami. Aby zataić prawdę o napaści, próbowano także przemilczać lub fałszować informacje - na przykład ukrywano, że Armia Czerwona przekroczyła granice kraju jeszcze zanim rząd II RP opuścił Warszawę i udał się do Rumunii. Propagowano fałszywą wersję wydarzeń, jakoby to najpierw rząd polski opuścił kraj przez most w Zaleszczykach, po czym Związek Radziecki, stwierdziwszy, że państwo polskie przestało istnieć, poczuł obowiązek ochrony bratnich mniejszości narodowych - Ukraińców, Litwinów i Białorusinów (była to swoista kontynuacja wersji zawartej w nocie dyplomatycznej przekazanej w dniu agresji polskiemu ambasadorowi przez Mołotowa) ${ }^{28}$.

Podobnej retoryki używano w PRL-u przy omawianiu tematu samego paktu Ribbentrop-Mołotow: przedstawiany był on wyłącznie jako pakt o nieagresji pomiędzy

25 Sprawę bardziej szczegółowo opisuje M. Wierzbicki w cytowanej pracy Polacy i Białorusini w zaborze sowieckim: stosunki polsko-białoruskie na ziemiach pótnocno-wschodnich II RP pod okupacją sowiecka (1939-1941), Warszawa 2007.

26 Tamże, s. 48-58.

Tamże, s. 67.

28 Historycy, 17 września 1939 - propaganda PRL, źródło: http://www.historycy.org/index. php?showtopic=76210 [dostęp: 8.07.2017]. 
III Rzeszą a Związkiem Radzieckim. O części tajnej dokumentu (a tak zgubnej dla II Rzeczpospolitej) nie mówiono w ogóle lub wręcz zaprzeczano jej istnieniu. Metody zatajania prawdy czy spłyconego, „okrężnego” opisu wykorzystywano również w kontekście polskich formacji militarnych: gdy pisano o powstaniu 1. Dywizji Piechoty im. T. Kościuszki (co miało miejsce dość często) lub Armii Andersa (w tym wypadku temat poruszano bardzo rzadko), używano mało konkretnego i opisowego zwrotu: „Polacy, których koleje wojny rzuciły w głąb Związku Radzieckiego”29.

\section{AGRESJA RADZIECKA - OBRAZ W ZSRR}

Wydarzenia z września 1939 roku w rosyjskich źródłach często noszą nazwę „polskiego pochodu Armii Czerwonej” (Польский похоА Красной армии), w radzieckiej historiografii wydarzenie nazywane było „wyzwoleńczym pochodem Armii Czerwonej".

Podobnie jak w propagandzie PRL-u, temat nazywany był „wyzwoleniem” lub pomijany i zatajany. W sowieckiej literaturze naukowej, zwłaszcza we wcześniejszym okresie powojennym, można było przeczytać: „Część Armii Czerwonej, z zachwytami witanej przez lud pracujący, oswobodziła Zachodnią Ukrainę i Zachodnią Białoruś spod znienawidzonego polsko-pańskiego ucisku polskich panów i obszarników”30. Nieco później, z powodu pojawiających się pewnych głosów krytyki, w publikacjach ograniczono się do określenia „wyzwolenie uciskanych Ukraińców i Białorusinów”31.

W okresie „chruszczowskiej odwilży” opis agresji sowieckiej został w radzieckiej historiografii ograniczony do „ochrony życia i majątku ludności” oraz do „pomocy ludności Zachodniej Ukrainy i Zachodniej Białorusi w obliczu groźby faszystowskiego zniewolenia”32. W pierwszym wydaniu (koniec lat pięćdziesiątych XX wieku) Ukraińskiej Sowieckiej Encyklopedii znalazła się natomiast treść: „Naród radziecki nigdy nie uznał zawłaszczenia zachodnioukraińskich ziem przez obcych imperialistów. $Z$ tego powodu, jeszcze w marcu 1923 roku, władze USRR wyraziły wobec ententy swój protest przeciwko okupacji terytoriów Zachodniej Ukrainy przez obszarniczoburżuazyjną Polskę" 33 .

9 Tamże.

В.Я. КАоков, Великий освободительный похоА Красной Армии. (Освобождение Западной Украины иЗападной Белоруссии), Воронеж 1940, s. 23.

Tamże, s. 24-27.

Tamże, s. 30.

33 М.П. Бажан, Украинская советская энциклопедия, ГАавная редакция Украинской советской энциклопедии, Киев 1957, s. 1253. 
Za pierwszy, najbardziej obszerny opis wydarzeń z września 1939 roku uznaje się rozdział Oswobodzenie Zachodniej Ukrainy i Białorusi, który pojawił się w pierwszym tomie Historii Wielkiej Wojny Ojczyźnianej Związu Radzieckiego 1941-1945 - tematowi poświęcono wówczas dwie i pół strony ${ }^{34}$. Później w dwunastotomowej publikacji Historia drugiej wojny światowej 1939-1945 „wyzwoleńczej misji Armii Radzieckiej” poświęcono już tylko kilka akapitów, a w trzecim tomie tej publikacji, wydanym w 1974 roku, można było znaleźć treść:

W rezultacie wyzwoleńczego marszu granica Związku Radzieckiego przesunęła się o 250-350 km na zachód. W takiej sytuacji Zwiąek Radziecki już w pierwszych tygodniach wojny przegrodzit drogę nadchodzacym wojkkom niemiecko-faszystowskim i pozbawit dowództwo niemieckie możliwości wykorzystania terytorium Zachodniej Ukrainy i Zachodniej Białorusi w charakterze przyczótka dla dalszej agresji $i^{35}$.

\section{WSPÓŁCZEŚNIE - POSTRZEGANIE 17 WRZEŚN1A 1939 ROKU W POLSCE}

Współcześnie w Polsce wkroczenie wojsk radzieckich do II Rzeczpospolitej 17 września 1939 roku traktowane jest jednoznacznie - jako agresja, podstępny atak bez wypowiedzenia wojny, można się także spotkać z określeniem, że realizacja tajnego postanowienia paktu Ribbentrop-Mołotow była początkiem „IV rozbioru Polski” ${ }^{36}$. Podkreśla się ponadto, że Związek Radziecki nie tylko zaatakował II Rzeczpospolitą bez oficjalnego wypowiedzenia wojny, lecz także złamał obowiązujący (teoretycznie do 1945 roku) pakt o nieagresji $i^{37}$.

Część polskich historyków (za przykład podać można prof. Pawła Wieczorkiewicza) podkreśla, że agresja sowiecka została zlekceważona na arenie międzynarodowej ${ }^{38}$, mimo że oceniając z perspektywy czasu, sowiecka agresja miała wplyw nie tylko na losy Polski, Białorusi i Ukrainy, lecz także na dalszy przebieg działań wojennych, późniejsze Москва, s.151.

История Великой Отечественной войны Советского Союза 1941-1945 г2. (в 6 томах), Военизаат,

35 Воссоединение украинского и белорусского народов, źródło: http://www.istorya.ru/book/ww2/136. php [dostęp: 10.11.2017].

36 P. Sierechan, Agresja ZSRR na Polskę 17 września 1939 r., źródło: https://polskiedzieje.pl/ii-wojnaswiatowa/agresja-zsrr-na-polske-17-wrzesnia-1939-roku.html [dostęp: 10.11.2017].

37 Wirtualna Polska, Co wydarzyło się 17 września 1939 r., źródło: https://wiadomosci.wp.pl/co-wydarzylosie-17-wrzesnia-1939-roku-6036278663472257a [dostęp: 10.11.2017].

38 Tamże. 
ukształtowanie granic ${ }^{39}$ oraz układu sił w Europie. Być może bez radzieckiej agresji przebieg drugiej wojny światowej byłby zupełnie inny ${ }^{40}$.

Pomimo zgodności co do oceny i postrzegania paktu Ribbentrop-Mołotow oraz czynu Armii Czerwonej jako agresji, współcześnie społeczna świadomość i pamięć o wydarzeniach z 17 września 1939 roku przedstawia się w Polsce różnie - wyniki ankiety przeprowadzonej w 2008 roku przez „Rzeczpospolitą” wykazały, że prawidłową wiedzę o wydarzeniach z tego dnia posiada co drugi ankietowany Polak ${ }^{41}$.

\section{WSPÓŁCZEŚNIE - BIA ŁORUŚ: „PIERWSI I DRUDZY SOW1EC1"}

Na Białorusi, należącej przez lata do Związku Radzieckiego, musiała dominować oficjalna, propagandowa wykładnia historii. Jednakże nie zawsze to, co zapisano w propagandowych podręcznikach, było zgodne z opinią społeczeństwa. Ta również przez lata (lata Związku Radzieckiego oraz lata budowania niepodległego państwa białoruskiego) ulegała zmianie. Mimo wielu lat propagandy i wysiłków, ideologom radzieckim nie udało się stłamsić i przekształcić historycznych faktów. I choć wśród zwolenników ideologii komunistycznej nawet dzisiaj może panować przekonanie o „wyzwoleńczym” marszu Armii Czerwonej, zdaje się, że w ogólnej świadomości działania sowieckie z września 1939 roku traktowane są jako akt agresji i bezprawne przekroczenie granicy II Rzeczpospolitej, z czym można się spotkać nie tylko w rozmowach na tematy historyczne, dyskusjach na internetowych forach, lecz także w części mediów ${ }^{42}$ oraz literatury naukowej i krajoznawczej. Za przykład służyć może praca Pierwsi Sowieci (Первые Советы) wołkowyskiego historyka i krajoznawcy Mikałaja Bychaucau, w której możemy przeczytać:

Termin „wyzwolenie”, którym nawet dziś postuguja się władze rosyjskie w kontekście agresji Armii Czerwonej z 17 września 1939 roku przeciw Polsce, przywołuje jedynie ironię. Stalin, wraz ze swoimi towarzyszami, nie mógt nieść wolności innym krajom, gdy w samym ZSRR miliony obywateli zostato eksterminowanych, a kolejne miliony znajdowały się w tagrach, wykonując niewolnicza pracę. Nie mógt Stalin, wraz ze swoimi bandytami $w$ uniformach NKWD, w tym samym czasie niszczyć wolności we własnym kraju i nieść jej innym społeczeństwom. Nie mógł ów „ojciec narodów" odziać i nakarmić obcego narodu, podczas gdy obywatele jego wtasnego

39 Tamże.

40 J. Łojek, dz. cyt., s. 9-10.

41 Wirtualna Polska, dz. cyt.

42 VirtualBrest, 17 сентября 1939 г.: объединение Западной Беларуси с БССР, źródło: http: //virtualbrest. by/news23186.php [dostęp: 16.09.2017]. 
kraju głodowali, podczas gdy robotnicy i chtopi nie mogli swobodnie kupić zwyktego sukna na suknię czy koszulę. Mimo wszystko wielu ideologów dzisiejszej Białorusi i Rosji wciąż zuporem mówi nam o wydumanym „wyzwoleniu” ${ }^{3}$.

Mimo pewnego przełomu w postrzeganiu wydarzeń z września 1939 roku i (można się odważyć na stwierdzenie) powszechnego uznania ich za agresję, a nie wyzwolenie, wciąż, nawet pośród białoruskich wrogów komunizmu i wielkich krytyków ZSRR, funkcjonuje pogląd, że wkroczenie wojsk radzieckich do Polski 17 września 1939 roku doprowadziło do zjednoczenia ziem białoruskich rozdzielonych po traktacie ryskim $^{44}$. Sprawę opisywał białoruski historyk Jurij Troponok:

Wodróżnieniu od białoruskiego, polski punkt widzenia na napaść z 1939 roku skupia się przede wszystkim na catkowitej stracie wschodnich terytoriów. Myśląc $w$ ten sposób, można przyznać, że traktat ryski był dla Białorusi nie mniej niemoralny i zbrodniczy w skutkach niz dla Polski pakt Ribbentrop-Mototow ${ }^{45}$.

Pojawiają się jednak dalsze refleksje na temat agresji sowieckiej oraz jej konsekwencji, także dla samych terytoriów Zachodniej Białorusi, która w wyniku „wyzwoleńczego pochodu” wyrwana została „spod polskiego ucisku” i połączona z białoruskimi ziemiami wschodnimi i całą resztą Związku Radzieckiego, by razem kroczyć ku „świetlanej przyszłości”. Owe refleksje i wnioski bywają gorzkie. W swojej pacy Mikałaj Bychowcew kontynuuje:

„Świetlana przyszłość” została narzucona siłą. Przybyli ze wschodu naczelnicy nie liczyli sięz miejscowymi tradycjami, obyczajami, porządkiem życia, narzucali swoje prawa, porządki i punkt widzenia. I nawet jeśli „przy Polakach” nie brakowato niesprawiedliwości, to byly to jedynie "kwiatuszki” w porównaniu z reżimem sprowadzonym ze Wschodu. Owszem, niektórzy zaczęli „żyć wesoło" przy nowych władzach, jednakże była to znacząca mniejszość ludności. Lecz mimo to w okresie wtadzy radzieckiej nam, zachodnim Białorusinom, sowiecki aparat propagandowy wmawiat, że bez 17 września 1939 roku do tej pory chodzilibyśmy w tapciach i wszyscy powszechnie byśmy się spolonizowali.

Historia jednak wszystko uporzadkowata. Teraz nietrudno porównać, komu żyje się lepiej - nam, czy Europie Zachodniej, gdzie nie zastosowano na ludności przestępczego eksperymentu, jakim byt komunizm. Rezultat porównania, niestety, nie jest dla nas korzystny. Co się tyczy polonizowania, to jakkolwiekby patrzeć, $w$ finalnym rozrachunku okazaliśmy się zrusyfikowani ${ }^{46}$.

Н.И. Быховцев, Первые Советы, Институт беларусской истории и культуры, Рига 2012, s. 3.

Przez niektórych Białorusinów traktat ryski jest traktowany jako rozbiór ziem białoruskich i rozdzielenie ich pomiędzy dwa państwa - II Rzeczpospolitą i Związek Radziecki.

Н.И. Быховцев, dz. cyt., s. 4.

Tamże, s. 5 
Można zadać sobie pytanie: który sposób postrzegania agresji radzieckiej jest na Białorusi bardziej „popularny” - ten radziecki, oparty na ideologii wyzwolenia, czy ten zmieniony, skłaniający się ku powszechnie uznanej prawdzie historycznej? Zdaje się, że odkłamanie historii (przynajmniej w kwestii samej napaści ZSRR) zakorzeniło się na tyle mocno w białoruskiej glebie, że nie da się jej wypielić i ponownie zasiać propagandowej wersji radzieckiej, choć dopóki na Białorusi istnieją relikty komunizmu i funkcjonują w sferze publicznej osoby związane z poprzednim systemem, dopóty ostatnie nuty sowieckiej ideologii i echa „wyzwolenia” odbijać się będą cichszym lub głośniejszym echem.

Niemniej jednak zwykli ludzie, mieszkańcy Zachodniej Białorusi, mają od lat swoją opinię dotyczącą nie tylko agresji sowieckiej z września 1939 roku, lecz także całego Związku Radzieckiego. W świadomości ludności Zachodniej Białorusi (a także po części Zachodniej Ukrainy) funkcjonują dwa pojęcia: pierwszych i drugich Sowietów. Mianem czasu „pierwszych Sowietów”, już w okresie powojennym, określano dwuletni okres w historii drugiej wojny światowej: od 1939 do 1941 roku. Po 1941 na omawianym obszarze nastał czas okupacji niemieckiej, a później powrót jurysdykcji radzieckiej, opisywany jako czas „drugich Sowietów”. Opinię społeczeństwa na temat tych wydarzeń, czasów oraz ich konsekwencji idealnie oddaje sens ludowego powiedzenia: „Pierwsi Sowieci byli lepsi od drugich - przybyli tylko na dwa lata i poszli, a drudzy zostali już na zawsze" ${ }^{\text {"7 }}$. 


\section{BIBLIOGRAFIA}

\section{W JEZZYKU POLSKIM:}

Boćkowski D., Na zawsze razem. Białostocczyzna i Łomżyńskie w polityce radzieckiej w czasie II wojny światowej (IX 1939-VIII 1944), Warszawa 2005;

Historycy, 17 września 1939 - propaganda PRL, źródło: http://www.historycy. org/index.php?showtopic=76210 [dostęp: 8.07.2017];

Historycy, II RP: ZSRR w prasie i publicystyce, źródło: http://www.historycy. org/index.php?showtopic=124971 [dostęp: 8.07.2017];

Kulski W.W., Pamiętnik b. polskiego dyplomaty, „Zeszyty Historyczne”, nr 42, Paryż 1977.

Łojek J., Agresja 17 września 1939, Warszawa 1990;

Poczobut A., \#Wrzesien1939, źródło: https://www.facebook.com/photo.php?-fb $\mathrm{id}=848635455302709 \&$ set $=$ pb. $100004687862170 .-2207520000.1510179812 . \&$ ty pe=3\&theater [dostęp: 9.11.2017];

Sierechan P., Agresja ZSRR na Polskę 17 września 1939 r., źródło: https:// polskiedzieje.pl/ii-wojna-swiatowa/agresja-zsrr-na-polske-17-wrzesnia-1939-roku. html [dostęp: 10.11.2017];

Stadnyi I., Obraz ZSRR w pitsudczykowskich czasopismach spoteczno-politycznych (1922-1939) [w: „NNowy Prometeusz” 2013, nr 4, s. 155-186;

Roszkowski W., Najnowsza historia Polski 1914-1945, Warszawa 2003;

Wieczorkiewicz P., Historia polityczna Polski 1935-1945, Warszawa 2005;

Wierzbicki M., Polacy i Biatorusini $w$ zaborze sowieckim: stosunki polskobiałoruskie na ziemiach pótnocno-wschodnich II RP pod okupacja sowiecka (1939-1941), Warszawa 2007;

Wirtualna Polska, Co wydarzyło się 17 września 1939 r., źródło: https:// wiadomosci.wp.pl/co-wydarzylo-sie-17-wrzesnia-1939-roku-6036278663472257a [dostęp: 10.11.2017];

Zyska J., Sowiecka propaganda we wrześniu 1939 r., źródło: http://www. nowastrategia.org.pl/sowiecka-propaganda-we-wrzesniu-1939-roku/ [dostęp: 10.07.2017].

\section{W JĘZYKU ROSYJSKIM:}

Virtual Brest, 17 сентлбря 1939 г.: объединение Западной Беларуси с БССР, источник: http://virtualbrest.by/news23186.php [dostęp: 10.11.2017] 
Бажан М.П., Украинскал советская энииклопедия, ГАавная реАакция Украинской советской энциклопеАии, Киев 1957;

Быховцев Н.И., Первые Советы, Институт беларусской истории и культуры, Рига 2012.

Воссоединение украинского и белорусского народов, źródło: http: / /www.istorya. ru/book/ww2/136.php [dostęp: 10.11.2017];

Аокаш О.Ю., Язык советской политической пропаганды в условиях экскалации военно-политического противостояния на западной Украине на начальном этапе второй мировой войны, Studia Humanitatis 2013, № 3, Москва;

История Великой Отечественной войны Советского Союза 1941-1945 г2. (в 6 томах), Воениздат, Москва;

Клоков В.Я., Великий освободительный поход Красной Армии. (Освобождение Западной Украины и Западной Белоруссии), Воронеж 1940;

Олийнык Н., Пропагандистская мичина „Золотого сентлбря”, Источник: http://www.radiopolsha.pl/6/249/Artykul/271036 [dostęp: 10.11.2017]. 